\title{
RELIGIUSITAS DENGAN FLOW AKADEMIK PADA SISWA
}

\author{
Arbi Alfarabi, Putri Saraswati, Tri Dayakisni \\ Fakultas Psikologi Universitas Muhammadiyah Malang \\ arbialfarabi28@gmail.com, putrisaraswati.mpsi@yahoo.com
}

\begin{abstract}
Problems in education are students who experience boredom in the learning process, whereas in the learning required concentration, interest and motivation, which required students to experience flow. Flow itself blends in total concentration which refers to the solemn concept in religiosity. The purpose of this research is to know religiosity relationship with academic flow. The design of this study is non-experimental correlation type. The data retrieval technique uses cluster sampling technique. Totals subjects as many as 222 students in city of Malang. Data collection method used in this research is the scale of religiosity made by the researcher. Then the scale of academic flow using the scale of LIS (The flow inventory for student), the researchers add some items in the scale of LIS. Data analysis method used product moment. The results of data analysis obtained $\mathrm{r}=0.508$ $\mathrm{p}=0.000$ ( $\mathrm{sig}<0.01)$ means that this study shows a significant positive relationship between religiosity and academic flow. While the effective contribution of religiosity to academic flow is $25.8 \%$ and the rest equal to $74.2 \%$, influenced by other factors.
\end{abstract}

Keywords: Religious, Academic Flow, Boredom.

\begin{abstract}
ABSTRAK
Permasalahan dalam pendidikan adalah siswa yang mengalami kebosanan dalam proses pembelajaran, padahal dalam pembelajaran dibutuhkan konsentrasi, minat dan motivasi, yang dibutuhkan siswa untuk mengalami flow. Flow sendiri menyatu pada konsentrasi total yang mana mengacu pada konsep khusyuk dalam religiusitas. Tujuan dari penelitian ini adalah untuk mengetahui hubungan religiusitas dengan flow akademik. Desain penelitian ini bersifat noneksperimen berjenis korelasional. Teknik pengambilan data mengugunakan teknik cluster sampling. Jumlah subjek sebanyak 222 siswa dikota Malang. Metode pengumpulan data yang digunakan dalam penelitian ini berupa skala religiusitas yang dibuat sendiri oleh peneliti. Kemudian skala flow akademik menggunakan skala LIS (The flow inventory for student), peneliti menambahkan beberapa item dalam skala LIS. Metode analisis data yang digunakan penelitian ini adalah product moment. Hasil analisis data diperoleh nilai $\mathrm{r}=0.508 \mathrm{p}=0.000(\mathrm{sig}<0.01)$ artinya penelitian ini menunjukan hubungan yang signifikan yang positif antara religiusitas dan flow akademik. Adapun sumbangan efektif dari religiusitas terhadap flow akademik adalah sebesar $25.8 \%$ dan sisanya sebesar $74.2 \%$, dipengaruhi oleh faktor lain.
\end{abstract}

Kata Kunci: Religiusitas, Flow Akademik, Kebosanan

\section{PENDAHULUAN}

Permasalahan pendidikan di Indonesia semakin hari semakin menunjukan kualitas yang rendah, bukan hanya mengenai cara strategi pembelajaran, kurangnya motivasi, kebosanan ketika berada di kelas, dan masih banyak lagi permasalahan yang ada didalam dunia pendidikan. Berdasarkan hasil survei yang dilakukan oleh Indiana University
Bloomington pada tahun 2006-2009 terhadap 275.000 siswa SMA di Amerika, diketahui sebesar $65 \%$ siswa mengaku mengalami kebosanan di kelas paling tidak sekali dalam satu hari (Sparks, 2012).

Menurut survey yang dilakukan
Yazzie-Mintz dalam Furlong $(2014)$
menyebutkan bahwa kebosanan telah menjadi
karakter disetiap sekolah, yang rata-rata $66 \%$


remaja siswa SMA mengalami kebosanan di sekolah dan $17 \%$ siswa merasakan kebosanan didalam kelas. Kebiasan siswa di Indonesia ketika sudah mengalami kebosanan dalam kelas kebanyakan mencari aktivitas yang lain seperti bermain handpone, berbicara dikelas, menggambar dan lain-lain. Maka dari itu salah satu permasalahan yang sangat banyak dialami oleh siswa adalah kebosanan dalam kelas yang akan berdampak pada menurunnya tingkat konsentasi dan ketertarikan pada siswa dalam proses pembelajaran.

Durasi belajar siswa Indonesia termasuk yang terpanjang bila dibandingkan dengan negara maju seperti Finlandia dan Singapura. Di negara itu, jam mata pelajaran Matematika, misalnya, maksimal hanya 45 menit per sesi, sementara di Indonesia ada yang sampai 90 menit. Menurut Seto Mulyadi, Ketua Komisi Nasional Perlindungan Anak, menyatakan jam belajar anak Indonesia mencapai 1.400 jam pertahun, jauh melampui standar belajar yang telah ditetapkan UNESCO yaitu hanya 800 jam belajar, sedangkan rata-rata belajar untuk anak SMP dan SMA di Indonesia, menurut UNESCO, adalah 1.680 jam atau setara dengan 42 jam per minggu. Ini tentu jauh lebih lama dibandingkan dengan Negara maju seperti jepang yang hanya mencapai 30 jam, sedangkan perancis 32 jam dan Australia 25 jam.

Data di atas menunjukan sangat padat jadwal pendidikan di Indonesia, belum juga ditambah dengan kursus, bimbingan belajar, maka jadwal belajar siswa Indonesia sangat panjang dibandingkan dengan Negara-negara lainnya. Kurangnya melihat daya konsentrasi dalam kelas yang dapat mengakibatnya kebosanan pada siswa, jika siswa mengalami kebosanan maka siswa tidak dapat lagi mengelolah informasi baru secara maksimal dikarenakan menurunnya daya konsentrasi dan minat pada siswa.
Sebuah modal yang sangat penting bagi seorang siswa terlibat aktif dalam proses pembelajaran. Ketika siswa terlibat aktif dalam proses pembelajaran maka siswa mampu menjaga konsentrasi, merasa nyaman dan memiliki motivasi pada saat menjalani kegiatan belajar. Semakin menurunya konsentrasi belajar maka semakin sulit juga siswa memfokuskan perhatiannya kedalam proses belajar, hal ini menunjukan bahwa siswa sudah tidak memiliki minat lagi dalm proses belajar sehingga sulit berkonsentrasi.

Suatu keadaan dimana konsentrasi, minat dan motivasi menurun hal ini menunnjukan bahwa siswa belum mampu mengalami kondisi flow, adapun yang dimaksud dengan dengan flow. Flow adalah keadaan ketika seseorang sepenuhnya terserap ke dalam apa yang dikerjakannya, perhatiaannya hanya terfokus kepada pekerjaan yang dilakukannya. Keadaan flow adalah puncak dari kecerdasaan emosional yang membutuhkan perasaan senang dan bahagia Csikzentmihalyi ( Rogatko, 2009).

Jika seseorang siswa mampu berada dalam kondisi flow maka siswa tersebut akan melupakan lingkungan disekitarnya, seperti waktu berjalan dengan cepat, hal ini terjadi dikarenakan siswa melakukan sesuatu aktivitas yang sangat disukainya, sehingga menjadi sangat fokus dalam berkonsetrasi, sehingga membuat lupa diri dalam beraktivitas dengan semangat yang tinggi. Maka dari itu kondisi flow tidak terjadi secara tiba-tiba. Menurut (Csikszentmihalyi, Schinder \& Shernoff, 2003), untuk dapat mengalami flow siswa perlu berkonsentrasi, memiliki minat, dan bersemangat dalam melakukan suatu aktivitas. Individu yang mengalami flow biasanya terlibat secara intens di dalam kegiatan yang ia lakukan, sehingga tak jarang mereka cenderung untuk tidak sadar dengan waktu atau tempat.

Flow diketahui memiliki dampak positif terhadap performa belajar siswa. Hasil 
penelitian yang dilakukan oleh Shernoff (2003) menunjukkan bahwa siswa yang mengalami flow lebih mau untuk terlibat di dalam proses belajar, mengalami peningkatan performa akademik, lebih merasa bersemangat saat mendapat tugas yang cukup menantang, dan cenderung lebih baik dalam hal atensi, mood serta motivasi belajar dibandingkan siswa-siswa lain yang tidak mengalami flow.

Sangat penting sekali menjaga perasaan siswa dalam proses mengajar karena jika siswa mampu mengeluarkan emosi positif maka perasan senang akan meninbulkan perasaan senang (enjoyment), yang akan berdampak pada minat (intrinsic motivation) yang tinggi dalam proses belajar (asakawa, 2004). Siswa yang tidak dapat mengalami flow, memiliki kecenderungan mengalami kejenuhan dalam proses pembelajaran maka kondisi atensi dan mood siswa tersebut tidak dalam keadaan yang baik, sehingga tidak dapat fokus didalam proses pembelajaran.

Flow, yang mengacu pada konsentrasi total. Hal ini hampir sama dengan konsep khusyu' dalam beragama yang mana kekhusyu'an dapat diperoleh dalam melakukan ajaran-ajaran dalam agama. Karena khusyu' adalah sarana untuk mumbuhkan kemampuan konsentrasi pikiran yang sangat mempengaruhi aktivitas yang dilakukan. Khusyu' mengharuskan seseorang yang shalat untuk menjaga konsentrasinya pada saat shalat, sehingga jika dilakukan terus-menerus maka ia akan menumbuhkan kemampuan konsentrasi yang akan menjadi faktor pendukng dalam aktivitas lainnya.

Konsep khusyu' tidak hanya diterapkan dalam ritualitas saja, akan tetapadi dalam segala aspek kehidupan sangat membutuhkan kekhusyu'an, seperti Firman Allah, yang berbunyi :

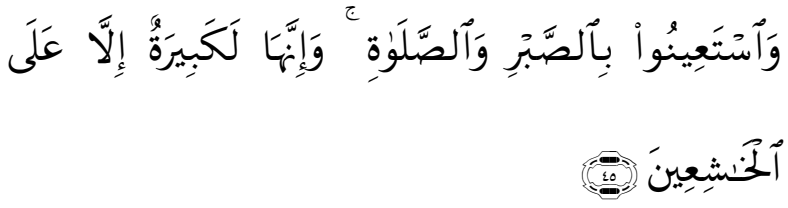

Artinya :

"Dan mohonlah pertolongan (kepada Allah) dengan sabar dan salat. dan (salat) itu sungguh berat, kecuali bagi orang-orang yang khusyu." (Qs. Al-Baqarah (2): 45).

Willian Molton, salah seorang ahli ilmu jiwa menegaskan : kemampuan konsentrasi pada laki-laki yang terpandang berjalan menurut alur kebiasaanny. Kemudian ia memaparkan bahwa cara mendapatkan kemampuan konsentrasi tersebut dengan cara melatih kesabaran, sehingga peralihan dari kesemrawutan berfikir menuju konsentrasi berfikir.

Selain itu shalat dalam kepercayaan umat muslim sebagai ritualistik yang terbaik, karena shalat melmiliki keutamaan yang besar bagi jiwa seperti kebahagiaan dan emosi positif lainnya, karena orang yang melaksakan shalat dengan khusyu' akan merasakan kebahagiaan dalam hidupnya. Penelitian yang dilakukan oleh Rogatko (2009) menjelaskan bahwa emosi yang positif dapat mempengaruhi kondisi flow pada mahasiswa. Menurut Csikzentmihakyi ketika seseorang ingin mengakami flow maka seseorang harus memiliki perasaan bahagia, karena ketika melakukan aktivitas dengan diiringi perasaan bahagia maka seseorang tersebut akan mudah mengalami flow. Menurut Han (Compton, 2005), flow dapat dirasakan dalam kegiatan ritual keagamaan.

Hawari (1996) menyebutkan bahwa religiusitas merupakan penghayatan keagamaan dan kedalaman kepercayaan yang diekspresikan dengan melakukan ibadah sehari-hari, berdo'a, dan membaca kitab suci. Menurut Najati (2003) manusia memiliki berbagai macam motivasi yang bersifar 
psikologis dan spiritual, yang mana motivasi ini memberikan kepuasan hidup, rasa aman, tentram dan bahagia. Koenig (Subandi, 2013) ditemukan bahwa agama banyak meningkatkan harapan dimasa depan, mengurangi tingkat depresi, rendahnya menglami kecemasan, memiliki (well being) dan kepuasan hidup yang lebih baik. Seperti halnya do'a yang diulang-ulang (repetitive prayer), ternyata akan membawa berbagai perubahan fisiologis pada tubuh, antara lain melambatnya gelombang otak dan pengurangan kecepatan metabolisme, yang mana kondisi ini disebut dengan respon relaksasi (relaxation response). Selain berdo'a, puasa juga mempengaruhi kecerdasan seseorang, hal ini dikaitkan dengan prestasi belajar. Ternyata orang yang sering berpuasa dalam tugas-tugas kolektif memperoleh sekor yang jauh lebih tinggi jika dibandingkan dengan orang yang jarang berpuasa (Ancok, 2003).

Seperti halnya shalat dalam agama islam, di dalam shalat memiliki sifat khusyu', yang mana menurut Ancok (Haryanto, 2007) kondisi shalat yang khusuk (tuma'ninah) memiliki efek seperti meditasi dan yoga. Penelitian yang dilakukan oleh Dillon dan Trait (2000) menunjukan bahwa atlit yang memiliki spiritual tinggi lebih mudah mengalami kondisi flow pada saat latihan.

Nashori (2007) menjelaskan bahwa secara sekilas dapat dilihat dari dalam (hati nurani) bahwa siapa yang mendekat kepada Tuhan, maka individu merasa lebih tenang kehidupannya. Siapa yang menjauh dari Tuhan, maka kehidupannya akan lebih diwarnai dengan stres dan ketidak tentraman.Ketidak tentraman siswa dalam kelas bisa diakibatkan dengan rendahnya tingkat religiusitas pada setiap diri individu, karena tidak mampu mengkontrol mood dan motivasi dalam proses pembelajaran yang mengakibatkan siswa susah mengalami Flow. Menurut bakker (2005) flow memiliki dampak yang positive dalam aktivitas individu, seperti dalam pendidikan, pekerjaan, hubungan intrepersonal, olahraga, keagamaan dan musik. Walaupun setiap agama memiliki ritual yang berbeda tapi ketika penganut agama memiliki keseriuasan dalam ritualnya maka akan merasakan "feeling of being the zone". Mengacu kepada permasalahan tersebut maka, peneliti tertarik untuk mnegkaji secara empiris dengan mengadakan sebuah penelitian yang berjudul "Hubungan tingkat religiusitas dengan flow akademik pada siswa". Tujuan dari penelitian ini untuk megetahui hubungan antara religiusitas terhadap flow akademik pada siswa. Manfaat penelitian ini untuk siswa adalah memberikan sebuah informasi mengenai pentingnya religiusitas terhadap flow akademik, untuk guru dapat memberikan sumbangan pengetahuan baru dalam memberikan kenyamanan siswa dalam kelas, menerapkan ilmu-ilmu agama dalam aktivitas pebelajaran, dan untuk ilmu psikologi dapat menjadi bahan rujukan pada bidang psikologi pendidikan.

\section{METODE PENELITIAN}

\section{Rancangan Penelitian}

Penelitian ini merupakan penelitian kuantitatif berjenis korelasional. Studi korelasi digunakan untuk mencari hubungan antara 2 variabel atau lebih (Winarsunu, 2007). Pernyataan dasar dalam penelitian korelasional adalah seberapa kuat kedua variabel berkorelasi satu sama lain, dan arah korelasi (searah atau berbanding terbalik).

\section{Subjek Penelitian}

Populasi adalah seluruh individu yang dimasukan untuk diteliti dan nantinya akan dikenai generalisasi (Winarsunu, 2007). Generalisasi adalah suatu cara untuk pengambilan kesimpulan terhadap kelompok individu yang lebih luas jumlahnya berdasarkan data yang di peroleh dari sekelompok individu yang lebih efektif. Dari penjelasan tersebut populasi dari penelitian ini 
adalah semua siswa SMAM dan MA Muhammadiyan dikota Malang. Sampel adalah anggota-anggota yang mencerminnkan sifat dan ciri-ciri yang terdapat di populasi (Winarsunu, 2007). Adapun besarnya populasi dalam penelitian ini adalah siswa 317 siswa dan yang menjadi subjek penelitian berjumlah 222 siswa dari SMAM dan MA Muhammadiyah dikota Malang.

Metode yang digunakan dalam pengambilan sampel pada penelitian ini menggunakan probability sampling, yaitu teknik pengambilan sampel yang memberi peluang/kesempatan sama bagi setiap unsur atau anggota populasi untuk dipilih menjadi sampel. Sedangkan teknik pengambilan sampel menggunakan metode Cluster sampling, yaitu teknik penentuan sampel dari populasi yang dilakukan dengan cara memilih sampel yang didasarkan pada klusternya bukan pada individunya.

\section{Variabel dan Instrument Penelitian}

Pada penelitian ini, terdapat satu variabel bebas dan satu variabel terikat. Adapaun yang menjadi variabel bebas adalah religiusitas dan yang menjadi variabel teritikat adalah flow akademik.

Flow akademik merupakan suatu kondisi, dimana siswa mencapai titik fokus dalam proses pembelajaran. Untuk mengukur flow akademik mengadaptasi skala the flow inventory for student (LIS) yang dikembangkan oleh Yuwanto (2011), yang berlandaskan teori Csikszentmihaly \& Shernof. Skala LIS ini memiliki 10 butir pernyataan yang bersifat favourable, dan peneliti menambahkan 2 pernyatan yang bersifat favourable dan menambahkan 12 pernyataan yang bersifat unfavorable, sehingga total item dalam skala ini berjumlah 24 item. Ada empat pilihan jawaban, yaitu sangat sesuai diberikan nilai 4, sesuai diberikan nilai 3, tidak sesuai diberikan nilai 2, dan sangat tidak sesuai diberikan nilai 1 .

Religiusitas merupaakan keyakinan, nilai dan perilaku yang terlembagakan, yang semuanya berpusat pada persoalan yang dihayati sebagi bentuk maknawi. Untuk mengukur religiusitas menggunakan skala religiusitas yang dibuat sendiri oleh peneliti yang berlandaskan teori Glock \& Stark. Skala ini memiliki 50 butir item yang terdiri dari pernyataan favorable dan unfavorable. Skala ini , mengukur lima aspek dari religiusitas, yaitu: dimensi kenyakinan (ideologis), dimensi peribadatan atau praktek keagamaan (ritualistic), dimensi penghayatan (eksperiensial), dimensi pengamalan (konsekuensial), dimensi pengetahuan (intelektual).

Dari 50 item skala religiusitas yang diujikan, ada 37 item yang valid dan memiliki reliabilitas 0.918 setelah diujikan melalui uji statistic menggunakan program SPSS versi 21.00. Indeks validitas dari skala religiusitas berkisar antara $0.307-0.603$. selain itu, dari 24 item skala Flow academic yang diujikan, ada 17 item yang valid dan memiliki nilai reliabilitas 0.841 setelah diujikan melalui uji statistic menggunakan program SPSS versi 24.00. Indeks validitas dari skala religiusitas berkisar antara 0.318 0.570 .

\section{Prosedur Penelitian dan Analisis Data}

1. Tahap persiapan

a. Menentukan, menyusun, dan menyiapkan instrument penelitian

b. Mengurus perizinan ke kepala sekolah MA I Muhammadiyah Malang untuk melakukan try out yang berlangsung pada tanggal 7-12 agustus 2017.

c. Melakukan uji validitas dan reliabilitas terhadap hasil try out.

d. Pada tanggal 14 agustus 3017. Mengurus perizinan ke kepala sekolah SMA I 


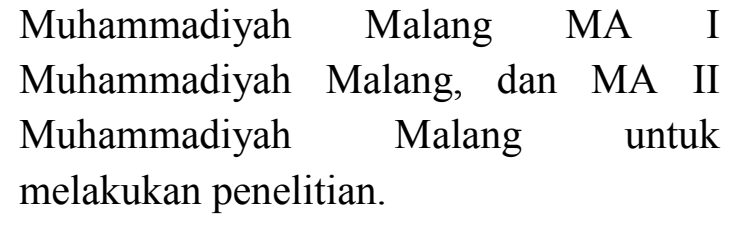

2. Tahap pelaksanaan

Penyebaran skala yang sudah valid dan reliabel dilakukan pada tanggal 25 agustus 2017 di MA II Muhammadiyah Malang, sedangkan penyebaran di MA I Muhammadiyah Malang dilaksanakan pada tanggal 4 - 5 september 2017, dan sedangkan penyebaran skala di SMA I Muhammadiyah Malang dilaksanakan pada tanggal 2 september 2017.

\section{Tahap akhir}

Pada tanggal 12-13 september 2017 dilakukan skoring dan entry data dan proses analisa data. Dalam proses penelitian ini menggunakan software perhitungan statistic SPSS for windows versi 21.00. selanjutnya data dianalisis dengan uji korelasi product moment karena penelitian ini menguji hubungan antara satu variabel bebas dengan satu varibel terikat.

\section{HASIL DAN PEMBAHASAN \\ Deskripsi Subjek}

Jumlah subjek yang digunakan dalam penelitian ini berjumlah 222 subjek dengan jenis kelamin laki-laki dan perempuan, yang sedang menempuh jenjang pendidikan SMAM dan MA Muhammadiyah dikota Malang. subjek dari penelitian ini emiliki rentang Usia dari $16-18$ tahun dan jumlah subjek yang berjenis kelamin laki-laki sebanyak 113, dan sedangkan subjek yang berjenis kealammin perempuan sebanyak 109 siswi. sedang menempuh pendidikan Sekoalah Menengas Atas (SMA) dan Madrasalah Aliyah (MA) di kota malang.

Tabel 1. Korelasi religiusitas dengan flow akademik

\begin{tabular}{l|l}
\hline \multicolumn{1}{c|}{ Koefisien korelasi $(\mathrm{r})$} & \multicolumn{1}{|c}{$\begin{array}{l}\text { Indeks } \\
\text { Analisa }\end{array}$} \\
\hline Koefisien korelasi $(\mathrm{r})$ & 0.508 \\
Koefisien determinasi $\left(\mathrm{r}^{2}\right)$ & 0.258 \\
Taraf kemungkinan kesalahan & $1 \%(0.01)$ \\
$P$ (Nilai signifikan) & 0.000 \\
\hline
\end{tabular}

Berdasarkan tabel di atas didapatkan nilai koefisien korelasi yang didapatkan dari perhitungan SPSS, diperoleh koefisien korelasi (r) sebesar 0.508 dengan nilai signifikan (p) sebesar $0.000<0.01$ yang menunjukan bahwa adanya hubungan yang positif antara religiusitas dan flow akademik, pada taraf kesalahan sebesar 1\%. Dari hasil penelitian ini, diperoleh juga koefisien determinasi variabel $\left(\mathrm{r}^{2}\right)$ sebesar 0.258 . adapun sumbangan efektif dari religiusitas terhadap flow akademik adalah sebesar $25.8 \%$ dan sisanya sebesar $74.2 \%$, dipengaruhi oleh variabel lain yang tidak diteliti dalam penelitian.

Tabel 2. Religiustitas T-Skor

\begin{tabular}{l|l|l}
\hline Kategori & Frekuensi & Presentasi \\
\hline Tinggi & 116 & $52.3 \%$ \\
Rendah & 106 & $47.7 \%$ \\
\hline Total & 222 & $100 \%$ \\
\hline
\end{tabular}

Berdasarkan tabel di atas didapatkan hasil yaitu 116 subjek termasuk kedalam kategori religiusitas tinggi yang apabila di presentasikan menjadi 52,3\% yang beberarti sisanya 47,7 atau 106 subjek termasuk kedalam kategoti religiusitas rendah datri total subjek yang digunakan sebanyak 222 subjek yang digunakan sebagai sampel.

Sedangkan hasil untuk perhitungan T-Skor skala Flow akademik adalah sebagai berikut.

Tabel 3. Flow akademik T-Skor

\begin{tabular}{l|l|l}
\hline Kategori & Frekuensi & Presentasi \\
\hline Tinggi & 127 & $57.2 \%$ \\
Rendah & 95 & $42.8 \%$ \\
\hline Total & 222 & $100 \%$ \\
\hline
\end{tabular}


Berdasarkan tabel di atas didapatkan hasil yaitu 127 subjek termasuk kedalam kategori religiusitas tinggi yang apabila di presentasikan menjadi $57,2 \%$ yang beberarti sisanya $42,8 \%$ atau 95 subjek termasuk kedalam kategoti religiusitas rendah datri total subjek yang digunakan sebanyak 222 subjek yang digunakan sebagai sampel.

Hasil dari penelitian ini membuktikan bahwa ada hubungan yang positif antara religiusitas dengan flow akademik, semakin tinggi tingkat religiusitas maka semakin tinggi pula flow akademik yang dirasakan, atau semakin rendah tingkat religiusitas maka semakin rendah pula flow akademik yang dirasakan. Religiusitas memiliki nilai koefisien $\left(\mathrm{r}^{2}\right)$ sebesar 0.258 , yang menunjukan variabel religiusitas memberikan pengaruh 25.8\% terhadap kondisi flow akademik yang berarti terdapat variabel lainnya sebesar $74.2 \%$ yang mempengaruhi kondisi flow akademik. Hasil dari penelitian yang telah dilakukan bahwa religiusitas memiliki hubungan dengan flow akademik dengan nilai signifikan (p) sebesar $0.000<0.01$.

Dari identifikasi di atas, diketahui bahwa banyak siswa yang mengalami kondisi flow saat proses pembelajaran, ini disebabkan karena siswa memiliki tingkat religiusitas yang tinggi, sehingga siswa mampu mengalami kondisi flow pada proses pembelajaran. Dengan demikian siswa yang sulit mengalami kondisi flow memiliki tingkat religiusitas yang rendah yang menunjukan bahwa siswa kurang mampu menjaga atensinya ketika proses pembelajaran berlangsung. Begitupula sebaliknya, ketika siswa memiliki tingkat religiusitas yang tinggi maka siswa akan mudah mengalami kondisi flow, yang mana siswa mampu menjaga atensinya dalam proses pembelajaran, yang menyebabkan siswa mampu fokus dan menikmati proses pembelajaran.
Ketika dilihat dari hasil penelitian ini menunjukan bahwa ada hubungan yang signifikan antara tingkat religiusitas dengan flow akademik pada siswa, semakin tinggi tingkat religiusitas maka semakin mudah siswa mengalami kondisi flow akademik. Dan besar pengaruhnya $25.8 \%$, dengan demikian bisa dikatakan bahwa ada beberapa faktor lain yang mempengaruhi flow akademik, seperti tingkat kemampuan (skills) yang dimiliki siswa dan tantangan (challenge) yang dihadapi siswa.

Sesuai dengan penelitian yang dilakukan oleh Dillon \& Tait (2000) yang melakukan penelitian religiustas atau spiritualitas dengan flow pada atlet olah raga yang mana menunjukan bahwa semakin tinggi spiritualitas atlet maka semakin mudah mengalami flow (zone) pada sesi latihan. Penelitian di atas didukung oleh penelitian Brown (2006) yang menunjukan bahwa religiusitas memiliki hubungan dengan flow dalam kegiataan sosial dalam agama, seperti beribadah atau meditasi. Menunjukan bahwa flow lebih mudah dialami dalam kegiatan peribatadan agama yang situasi sosial dari pada peribadatan yang dilakukan secara individu.

Siswa yang memiliki religiusitas tinggi akan mudah megalami kondisi flow akademik, karena religiusitas memiliki kemiripan dengan konsep flow akademik. Hal ini mengacu pada konsep konsentrasi yang dimiliki oleh flow akademik, siswa akan mudah mengalami kondisi flow akademik jika siswa mampu menjaga titik fokusnya pada proses pembelajaran. Seperti halnya dalam salat dalam kegiatan ritual agama islam, yang mengharuskan berkonsentrasi (khusyuk) dalam ibadah salat. Pernyataan ini sesuai dengan temuan Doufesh, dkk. (2016) menunjukan bahwa shalat memiliki efek yang sama dengan metidasi dalam hal focus attention, karena para pelaku mampu 
mengendalikan diri dari pengaruh-pengaruh dan gangguan dari luar dirinya.

Focus attention sendiri adalah suatu kondisi dimana seseorang fokus pada objek tertentu, yang mana hal ini mampu didapatkan ketika dalam salat dan sebagai salah satu efek dari salat. Dalam dunia pendidikan sangat dibutuhkan sekali kemampuan kognitif (cognitive abilities), karena mampu membantu siswa berkonsentrasi dan memfokuskan pikiran dalam proses pembelajaran. Kemampuan seperti ini mampu didapatkan dalam kegiatan ritual seperti salat, dzikir, dan lain-lain.

Kekhusyukan dalam salat dapat dialami jika siswa mengetahui makna bacaan dalam salatnya, bagaimana bisa seseorang khusyuk jika ia sendiri tidak mengerti apa yang diucapkannya, maka dari itu hal terpenting dalam khusyuk adalah mengerti atau memahami makna dari setiap bacaan dalam salatnya. Ketika seseorang memahami setiap bacaannya maka seseorang itu akan menghayati setiap bacaan dan gerakan dalam salatnya, jika seseorang itu mampu menghayati maka ia kan merasakan ketenangan jiwa. Ketenangan jiwa yang ditimbulkan dalam salat juga membantu menghilangkan kegelisahan dan ketenangan pikiran yang biasanya berlangsung ketika setelah salat.

Salat lima waktu sehari memberikan sebaik-baik cara dalam latihan dan belajar relaksasi. Ketika seseorang belajar relaksasi, biasanya ia mampu melepaskan diri dari tekanan saraf yang ditimbulkan oleh tekanan dan kecemasan hidup. Menurut Adi (Haryanto, 2007) semakin rajin seseorang malakukan salat, maka semakin rendah tingkat kecemasannya. Hal ini menunjukan bahwa salat mampu mereduksi sensitivitas emosi yang membawa siswa dalam kondisi yang tenang dan ketenagan dalam pikiran.

Siswa yang menjaga keadaan khusyuk dalam salatnya mampu membantu dirinya mencapai kondisi flow akademik, karena peran khusyuk sebagai sumber ketenangan dan sebagai sarana latihan berkonsentrasi. Selain itu salat dilakukan minimal lima kali dalam sehari, hal ini menunjukan adanya perilaku yang berulang-ulang (repetition), adapun yang dimaksud dengan repetition adalah mempratikkan kembali atau mengulangi sejumlah tindakan (Artur, 2010). Menurut Thorndike (Hergenhahn, 2012) bahwa law of exercise (hukum latihan) semakin sering tingkah laku diulang/dilatih maka perilaku tersebut akan semakin kuat. Maka dari itu jika kondisi khusyuk dilakukan secara terus-menerus maka akan menumbuhkan kemampuan konsentrasi yang akan menjadi faktor pendukung terpenting dalam mengerjakan aktivitas belajar.

\section{SIMPULAN}

Berdasarkan hasil penelitian yang telah dilakukan dapat disimpulkan bahwa hipotessa diterima. Jadi semakin tinggi tingkat religiusitas maka semkin tinggi pula flow akademik siswa, atau sebaliknya semakin rendah tingkat religiusitas maka semakin rendah juga flow akademik siswa. Beberapa implikasi penelitian ini adalah utuk peneliti selanjutnya disarankan untuk melekukan beberapa hal : 1) perlu dilakukan penelitan tentang pengaruh setiap aspek religiusitas terhadap flow akademik. 2) perlu dilakuakn penelitian lanjutan untuk mengukur flow akademik dengan variable lain, seperti spiritualtas, emosi positif dan negatif. 3) perlu juga dilakukan penelitian lanjutan untuk melihat apakah flow akademik dapat dipengaruhi jeniskalmin dan tipe kepribadian 4). Mengukur flow akademik dengan faktor ynag mempengaruhi (skills dan challenge). Implikasi untuk guru : 1) lebih meningkatkan kegiatan agama, seperti shalat berjamaah, mengaji (dimensi ritualistik). 2) meminimalisir tejadinya emosi negative dalam kelas. 3) memberikan tugas yang sesuai 
dengan kemampuan siswa. Implikasi untuk siswa: 1) meluangkan waktu untuk mendekatkan diri kepada Allah. 2) menjaga emosi-emosi positif dalam proses pembelajaran.

\section{DAFTAR PUSTAKA}

Ancok, D., Suroso, F. N. (2004). Psikologi islam solusi islam atass problemproblem psikologi. Yogyakarta : Pustaka Pelajar.

Arthur, S., reber \& Emily, R, Reber. (2010). Kamus Psikologi. Yogyakarta : Pustaka Pelajar.

Asakawa, K. (2004). Flow experience and autotelic personality in Japanese college students: How do they experience challenges in daily life? Journal of happiness Studies, 5(2), 123-154.

Bauman, N., Scheffer. D. (2010). Seing and mastering difficulty: the role of affective change in achievement flow. Cognition and emotion, 24:8, 13041328.

Bakker, A. B. (2005). Flow among music teacrher's and their students : the crossover of peak experiences. Journal of vocational behavior, 66, 24-44.

Brown, S. C. (2006). Religious Orientation and Flow. Master's Thesis, And Doctoral Dissertations Eastern Michigan University,Michigan.

Compton, C. W. (2005). Leisure optimal experience, and peak performance. $A n$ introduction To Positive Psychology. 4, 67-84.

Diener, E. D., \& Sligmen, M, E.P. (2002). Very happy people. Psychological science. Vol. 13, No. 1.

Dillon, K. M., \& Tait, J. L,. (2000). Sprituality and being in the zone in team sports: a relationship. Journal of sports behavior, 23(2), 91-100.
Doufesh, H., Ibrahim, F., Safari, M., (2016). Eeffects of muslim praying (salat) on EEG Gamma Activity. Complementary therapies in clinical practice.doi 10.10 16/j.ctcp.2016.04.004.

Engeser, S., Rheinbergh, F. (2008). Flow, performance and moderators of challenge Skill balance. Springer science+business. DOI 10.1007/s11031-008-9102-4

Furlong, J. M., Gilman, R., Heubner, E. S. (2009). Handbook of positive psychology in schools. Flow in schools revisited: cultivating engaged learners and optimal learning environment. 14. 211-126.

Hardawi, D. (1997). Al-qur'an ilmu kedokteran jiwa dan kesehatan jiwa. Jakarta : Dana Bhakti Prima Yasa. Hergenhahn. B. R., Olson. M. H. (2010). Theory of Learning (Teori Belajar). Jakarta: Kencana.

Mikicin, M. (2007). Relationship between experience flow state and personality traits, locus of Control and achievement motivation in swimmer.

Osin, E. V., Malyutina, V. A., Kosheleva, V. N. (2016). Self-transendence facilitates Meaning-making and flow: evidence from a pilot experimental study. Psychology in rusia: state of the art. Vol 9. No. 2. 80-9

Haryanto, S. (2007). Terapi religius psikologi sholat kajian aspek-aspek psikologis ibadah shalat (Ed.revisi). Yogyakarta : Pustaka Pelajar

Shernoff, D.,J Csikszentmihalyi, M., Schneider, B., \& Shernoff, E.,S. (2003). Student engagmentin high school classroom from the perspective of flow theory. School psychology quarterly, 18, 158-176. 
Spark, D. S. (2012). Studies link student boredom to stress. Education Week Online.

Subandi, M. A. (2013). Psikologi agama \& kesehatan mental. Yogyakarta : Pustaka Pelajar.

Rogatko, T. P. (2009). The influence of flow on positive affect in college student. Journal of happiness studies, 10, 133148.

Yuwanto, L. (2011). The flow inventory for student: validation of LIS. Aniama, indonesian psychological journal. 26 (4), 281-286.

Winarsunu, L. (2007). Statistik dalam penelitian psikologi dan pendidikan. Malang: Umm Press. 